\title{
Portal-Systemic Encephalopathy in Emergency Treatment of Cirrhosis and Bleeding Esophageal Varices
}

\author{
Marshall J. Orloff \\ University of California, San Diego, Medical Center
}

USA

\section{Introduction}

Bleeding esophageal varices (BEV) is a common and highly lethal complication of cirrhosis of the liver (Graham \& Smith, 1981; Smith \& Graham, 1982; Burroughs et al., 1989; Bornman et al., 1994; Khan et al., 2006; Orloff et al., 1977; Mikkelsen, 1974; Terblanche et al., 1989; \& D'Amico et al., 1995) The mortality rate associated with BEV is highest during the period surrounding the episode of acute bleeding. If the varices remain untreated after recovery from a bout of acute bleeding, we (Orloff et al., 1977) and others observed a 95\% incidence of recurrent bleeding, and death within 2 to 5 years in $90 \%$ to $100 \%$ of the patients. Recurrent bleeding has been reported to develop most often within the first few days after the acute bleeding episode (Graham \& Smith, 1981; Smith \& Graham, 1982). Thus, it is clear that emergency treatment of acute bleeding is of paramount importance in the care of patients with portal hypertension and esophagogastric varices.

Because of the over-riding importance of emergency treatment of variceal bleeding, from 1958 to 2011 we conducted and reported studies of emergency therapy in patients with cirrhosis (Orloff, 1967; Orloff et al., 1980; Orloff et al., 1992); Orloff et al., 1994; Orloff et al., 1995a; Orloff et al., 2009a; Orloff et al., 2009b; Orloff et al., 2011a; Orloff et al., 2011b; Orloff et al., 2010; Orloff et al., 2011c; Orloff et al., 2011d; Orloff et al, 2011e; Orloff et al., 2011f; Orloff et al., 2011g; Orloff et al., 2011h; Orloff et al., 2011i). Our studies have been distinguished by three features that, together, make them different from other reported investigations. All patients admitted to our institution with cirrhosis and BEV ("all comers"), regardless of their condition, were included without selection; the specific emergency treatment undergoing evaluation was administered within 24 hours and usually within 8 hours of initial contact; and our studies were prospective, meaning that a welldefined protocol was consistently used and data were collected on-line. Evaluation, prevention, and treatment of portal-systemic encephalopathy (PSE) were an important part of each of our studies.

\section{The Eck fistula}

In 1877, Nikolai V. Eck (1849-1908), a 29-year-old military surgeon working in the Military Medical Academy in St. Petersburg, published a brief article describing his experiments and 
technique for creating a portacaval shunt (Eck fistula) in eight dogs (Eck, 1877). This was not only the beginning of the surgical treatment of portal hypertension but also the first vascular anastomosis. In his article, Eck stated: "I am conducting these experiments with the purpose of clarifying some physiologic problems as well as to determine whether it would be possible to treat some cases of mechanical ascites by means of forming such a fistula. I operated on 8 dogs, one recovered completely and lived in the laboratory for 2.5 months. Because of lack of attention, he ran away. I had to postpone further experiments because I was called to join the active army."

Eck's work would probably have remained unknown outside Russia had it not been for Ivan Pavlov (1849-1936), who used the procedure extensively in laboratory studies of liver physiology and named the operation the Eck fistula, giving full credit to Eck for its invention (Hahn et al., 1893; Pavlov, 1893). The landmark description by Pavlov et al. of portal-systemic encephalopathy (PSE) following feeding meat to dogs with an Eck fistula, which they called "meat intoxication," was part of the work that resulted in Pavlov's receiving the Nobel Prize in 1904 for his contributions on the physiology of digestion. Pavlov spent his entire career at the Military Medical Academy in St. Petersburg, the same institution where Eck developed the portacaval shunt. Since its original description, the Eck fistula has been used extensively for a wide range of studies in animals and humans and clinically for the treatment of the life-threatening complications of portal hypertension.

\section{Portal-Systemic Encephalopathy (PSE)}

Hepatic encephalopathy is a neuropsychiatric disorder that results from impaired liver function. It occurs in two distinct forms: (1) in acute or fulminant hepatic failure it takes the form of a neurological disorder that progresses from altered mental status to coma, generally within hours or days, and is associated with increased intracranial pressure caused by massive brain edema; (2) portal-systemic encephalopathy (PSE), which commonly occurs in cirrhosis, in which there are spontaneous or created portal-systemic shunts that permit toxins of intestinal origin to bypass the liver into the systemic circulation. Neurologically, PSE develops slowly, starting with sleep abnormalities, shortened attention span, and muscular incoordination, progressing through lethargy, ataxia, stupor, and coma. PSE is often precipitated by event such as gastrointestinal bleeding, uremia, hypokalemia, or ingestion of excessive amounts of protein. Neuropathologically, PSE is characterized by astrocytic rather than neuronal changes, and brain edema and intracranial hypertension are not found.

Since the description in 1893 of "meat intoxication" in the Eck fistula dog by the Pavlov group, animals with a portacaval shunt (PCS) (Eck fistula) have been used extensively for research studies of the pathogenesis and treatment of PSE (Hahn et al., 1893). The PCS rat has been consistently reported to have neurobehavioral abnormalities when subjected to sophisticated testing (Bengtsson et al., 1980; Tricklebank et al., 1978). One of the best animal models of chronic recurrent PSE is the dog with a congenital or surgically created PCS (Maddison et al., 1991). Animal and human studies have demonstrated that chronic liver failure and spontaneous or created PCS result in the accumulation of neurotoxic substances in the brain. Two such substances are ammonia and manganese.

Ammonia derived from colonic bacteria as well as from the deamination of glutamine in the small bowel is absorbed by passive diffusion and normally undergoes a high first-pass 
extraction by the liver (Cordoba \& Blei, 1997). In chronic liver failure, hepatic urea synthesis declines and this, in addition to portal-systemic shunting, results in increased blood ammonia concentrations. Furthermore, cirrhotic patients are hypersensitive to ammoniagenic conditions such as an oral protein load or gastrointestinal hemorrhage. An illustration of this hypersensitivity is provided by a report of studies in the 1950s in which attempts were made to treat ascites in cirrhotic patients with ion-exchange resins that absorbed sodium but released ammonium ions (Gabuzda et al., 1952). This treatment led to a significant reduction in ascitic volume but precipitated severe PSE in many of the patients treated. If present in high concentrations, ammonia has the potential to adversely affect central nervous system (CNS) function by several mechanisms, which include a direct effect of the ammonium ion on inhibitory and excitatory neurotransmission as well as inhibition of the tricarboxylic acid cycle enzyme ketoglutarate dehydrogenase, with potential impairment of brain energy metabolism (Szerb \& Butterworth, 1992; Lai \& Cooper, 1986) However, brain energy metabolism does not appear to be impaired in chronic liver failure until very late stages associated with isoelectric electroencephalography (EEG) traces (Hindfelt et al., 1977). On the other hand, increases of cerebrospinal fluid lactate have been described both in cirrhotic patients with PSE (Yao et al., 1987) and in experimental animals with chronic liver failure and ammonia-precipitated encephalopathy (Therrien et al., 1991), findings that are consistent with an inhibitory effect of ammonia on cerebral glucose oxidation.

Other effects of ammonia on cerebral function include a stimulatory effect on L-arginine uptake by brain preparations resulting in increased production of nitric oxide (Raghavendra Rao et al., 1995) and inhibition of the capacity of astrocytes to accumulate glutamate (Bender \& Norenberg, 1996; Knecht et al., 1997) a major excitatory neurotransmitter.

In 1963, we performed a study that subsequently influenced the use of PCS in the treatment of portal hypertension and variceal hemorrhage. We examined the influence of the stomal size of the portacaval anastomosis, and in turn of the blood flow rate through the anastomosis, on peripheral blood ammonia levels (Orloff et al., 1963). Induced ammoniemia was studied in two groups of dogs, one of which had large end-to-side PCS measuring at autopsy 2.0-4.2 cm in greatest diameter, and the other of which had small end-to-side PCS measuring $0.5-1.8 \mathrm{~cm}$ in greatest diameter. A third group of intact dogs served as controls. Ammoniemia was induced by three standardized methods that consisted of the administration by gavage of ammonium citrate $(0.5 \mathrm{~g} / \mathrm{kg})$, gavage of fresh whole blood (30 $\mathrm{mL} / \mathrm{kg})$ plus urease $(4 \mathrm{U} / \mathrm{mL})$, and gavage of fresh whole blood $(30 \mathrm{~mL} / \mathrm{kg})$ alone. All three techniques of ammonium loading resulted in significantly higher mean peak blood ammonia levels in the dogs with large shunts than in those with small shunts. Furthermore, in the animals with large shunts, markedly elevated blood ammonia concentrations persisted for longer periods of time. Measurements of the pressure gradients across the shunts at operation revealed a mean gradient of $31.0 \mathrm{~mm}$ saline in the small-shunt group as compared to only $3.0 \mathrm{~mm}$ in the large-shunt group. A consistent inverse relationship was demonstrated between the height of the blood ammonia level and the magnitude of the pressure gradient across the portacaval anastomosis. Application of Gorlins' hydraulic formula to these studies provided support for the presumption that the magnitude of ammoniemia was directly related to the blood flow rate through the shunt. We concluded that the stomal size of end-to-side PCS, and in turn the rate of blood flow through the shunts, have a definite influence on the concentration of ammonia in the peripheral blood of 
the dog. These results suggested the possibility of a relationship between shunt size and postshunt PSE. The results of this study served as the basis for the subsequent use of reduced-caliber PCS in the treatment of variceal bleeding (Sarfeh \& Rypins, 1994; Zervox et al., 1998).

In addition to ammonia, chronic liver failure and portal-systemic shunting result in increased blood and brain concentrations of manganese (López-Novoa, 1988; Fitzhugh \& Nelson, 1948; Dashti et al., 1989; \& Nuber et al., 1980). Manganese is neurotoxic, affecting both neuronal and astrocytic integrity. In the case of astrocytes, exposure to manganese results in altered expression of several key astrocytic proteins (Hazell et al., 1999a; Hazell et al., 1999b) and Alzheimer type II changes (Weissenborn et al., 1995).

Other toxins in addition to ammonia and manganese are known to increase in the systemic circulation in chronic liver failure. Such toxins include mercaptans, phenols, and short-chain fatty acids (Zieve et al., 1974). While there is no convincing evidence that these toxins alone cause cerebral dysfunction in chronic liver failure, they could combine with ammonia or manganese to act synergistically (Zieve, 1989).

Recently, attention has been focused on changes in brain neurotransmitter systems as the likely mediators of the neuropsychiatric manifestations of PSE in chronic liver failure. Recent studies using molecular biological approaches continue to confirm that, when liver fails, brain responds with significant alterations in gene expression. In many cases, these alterations involve genes that code for neurotransmitter-related proteins, many of which are essential for CNS function. Many of the symptoms of early PSE in chronic liver failure, such as altered personality, depression, and inverted sleep patterns, are symptoms that have classically been associated with alterations in biogenic amine function. FNA extracts of brain tissue obtained at autopsy from cirrhotic patients who died in hepatic coma have been found to show increased expression of the neuronal isoform of the monoaminemetabolizing enzyme MAO-A (Mousseau et al., 1997). This increase in MAO-A gene expression was found to be associated with increased activities of the enzyme and increased densities of catalytic sites on the enzyme protein (Mousseau et al., 1997). Moreover, studies of the same brain extracts revealed increased concentrations of homovanillic and hydroxyindoleacetic acids, the final metabolites of dopamine and serotonin, respectively (Bergeron et al., 1989). Increased concentrations of 5-hydroxyindoleacetic acid were also reported in cerebrospinal fluid from patients (Young \& Lai, 1980) and experimental animals (Bergeron et al., 1995) with chronic liver failure. On the basis of these findings, it has been suggested that altered monoaminergic function may be responsible for the early neuropsychiatric symptoms of PSE in chronic liver disease (Bergeron et al., 1995; Bergeron et al., 1990).

The "peripheral-type" benzodiazepine receptor (PTBR) is a heterooligomeric protein complex located (like MAO-A) on the outer mitochondrial membrane of the astrocyte. Increased PTBR gene expression has been reported in brain extracts from rats with PCS (Desjardins et al., 1997). This increased gene expression resulted in increased receptor sites in the brains and peripheral tissues of these animals as revealed by quantitative receptor autoradiography and the high selective PTBR ligant [ $\left.{ }^{3} \mathrm{H}\right]$ PK 11195 (Giguère et al., 1992; Raghavendra Rao et al., 1994). Increased [ $\left.{ }^{3} \mathrm{H}\right]$ PK 11195 binding sites were also reported in autopsied brain tissue from cirrhotic patients who died in hepatic coma (Lavoie et al., 1990). 
There is evidence to suggest that the increased expression of PTBRs in brain in chronic liver failure is the consequence of exposure to ammonia and/or manganese. The precise mechanism whereby increased expression or activation of PRBRs results in altered brain excitability characteristic of PSE has not been established. PCS in the rat results in increased gene expression of the constitutive (neuronal) isoform of nitric oxide synthase (nNOS) in brain (Raghavendra Rao et al., 1997a). Increased nNOS mRNA is accompanied by increased nNOS protein (Raghavendra Rao et al., 1997a) and by increased nNOS enzyme activities. Recent evidence suggests that, in addition to an induction in nNOS gene expression, increased nNOS activities may also result from a stimulatory effect of ammonia on Larginine uptake by neuronal preparations shown both in vitro and in vivo (Raghavendra Rao et al., 1997b). Increased production of $\mathrm{NO}$ as a consequence of increased nNOS activities could contribute to the alterations of cerebral perfusion observed in chronic liver disease (Raghavendra Rao et al., 1998).

The appearance of extrapyramidal symptoms, particularly rigidity, in cirrhotic patients with end-stage liver disease has prompted, by analogy with the well-established dopamine deficit in Parkinson's disease, evaluations of the dopamine system in relation to PSE. Studies in autopsied brain tissue from cirrhotic patients (Bergeron et al., 1989) and from rats with PCS (Bergeron et al., 1995) reveal several-fold increases in concentration of the dopamine metabolite homovanillic acid, a finding that could result from increased activities of monoamine oxidase reported in the same material (Mousseau et al., 1997). In another study, densities of the postsynaptic dopamine $\mathrm{D}_{2}$ receptor were significantly reduced in pallidum/putamen from cirrhotic patients (Mousseau et al., 1993) a finding that could have resulted from manganese deposition in the brains of these patients (Pomier Layrargues et al., 1995).

Strategies aimed at the prevention and treatment of PSE in chronic liver failure are of two major types, namely, ammonia-lowering strategies and approaches aimed directly at the CNS (Cordoba \& Blei, 1997; Ferenci et al., 1996). Since PSE is frequently precipitated by ammoniagenic situations such as an oral protein load or a gastrointestinal hemorrhage, various treatment modalities are aimed at the gut. Such strategies include reduction of the absorption of nitrogenous substances arising from bacterial action in the colon. Colonic cleansing reduces the luminal ammonia content and lowers blood ammonia content in cirrhotic patients (Wolpert et al., 1970). Nonabsorbable disaccharides are routinely used to decrease ammonia production in the gut. The action of the most popular substance in this class, lactulose, involves increased fecal nitrogen excretion by facilitation of the incorporation of ammonia into bacteria as well as a cathartic effect (Cordoba \& Blei, 1997). Lactulose administered orally reaches the cecum, where it is metabolized by enteric bacteria, causing a fall in $\mathrm{pH}$ (Brown et al., 1974). The dose is adjusted to produce two or three soft bowel movements daily (Cordoba \& Blei, 1997).

Antibiotics such as neomycin are also useful for lowering blood ammonia, mainly by an effect on ammonia production by intestinal bacteria. However, neomycin therapy may be associated with some toxic side effects (Cordoba \& Blei, 1997). More recently, rifaximin, a nonabsorbable derivative of the antibiotic rifamycin, has been shown to be effective in lowering blood ammonia and has proven to be of superior efficacy compared with lactulose (Bismuth et al., 2011; Munoz, 2008). Most of an orally administered dose is eliminated unchanged in the feces. Thus, it lacks significant toxicity and side effects because of minimal gastrointestinal absorption. 
Restriction of dietary protein remains a cornerstone of therapy for PSE in cirrhotic patients and has been an essential part of our treatment of patients with bleeding esophageal varices following portacaval shunt (Wolpert et al., 1970). However, long-term nitrogen restriction is potentially harmful and a positive nitrogen balance is necessary to promote liver regeneration as well as to increase the capacity of skeletal muscle to remove ammonia in the form of glutamine (Lockwood et al., 1979). Protein intake of $1 \mathrm{~g} / \mathrm{kg}$ per day may be required in order to maintain an adequate nitrogen balance (Swart et al., 1989).

An alternative strategy for the lowering of blood ammonia is the stimulation of ammonia fixation (Desjardins et al., 1997). Under normal physiological conditions, ammonia is removed by the formation of urea in periportal hepatocytes and by glutamine synthesis in perivenous hepatocytes, skeletal muscle, and brain. In cirrhosis, both urea cycle enzymes and glutamine synthetase in liver are decreased in activity. Strategies to stimulate residual urea cycle activities and/or glutamine synthesis have been tried over the past 20 years. One of the most successful agents to be used so far is L-ornithine-L-aspartate (OA). RCTs with OA demonstrate significant ammonia lowering and concomitant improvement in psychometric test scores in cirrhotic patients with PSE (Kircheis et al., 1997). Studies in experimental animals suggest that the metabolic basis for the beneficial effect of OA on blood ammonia in chronic liver failure resides in its ability to stimulate residual hepatic urea cycle function and also to promote glutamine synthesis, particularly in skeletal muscle (Rose et al., 1998).

Benzoate is also effective in reducing blood ammonia both in patients with inherited urea cycle disorders and in cirrhotic patients [64]. In a RCT with sodium benzoate versus lactulose, improvement in neuropsychiatric performance was found to be comparable using both treatments (Sushma et al., 1992).

In contrast to the multiple strategies used successfully to lower blood ammonia and improve neurological status in patients with chronic liver failure, drugs that act directly on neuronal excitability have not been widely applied in this patient group. The major reason for this is that the precise neurotransmitter changes responsible for PSE in chronic liver failure are still being elucidated. Some attempts to treat PSE in cirrhotic patients with benzodiazepine receptor antagonists and dopamine agonists have occurred, but with limited success.

Several RCTs have been performed to assess the efficacy of the benzodiazepine receptor antagonist flumazenil in cirrhotic patients with various degrees of severity of PSE [69]. Spectacular improvements in neuropsychiatric status were recorded in a subset of patients receiving flumazenil (Pomier Layrargues, 1994; Gyr et al., 1996). However, enthusiasm for this approach has been tempered by the possible confounding effects of prior exposure to benzodiazepines and the seeming lack of correlation between clinical response and blood levels of substances with benzodiazepine receptor agonist properties in these patients (Butterworth et al., 1995).

\section{Emergency portacaval shunt for bleeding esophageal varices}

Portal-systemic shunt is the only available definitive treatment for portal hypertensionrelated bleeding. Numerous studies have shown that a technically satisfactory PSS will permanently solve the problem of bleeding in the vast majority of patients. The obvious 
potential advantage of performing this procedure under emergency circumstances is that, unlike other forms of treatment, it can be expected to provide both immediate and prolonged control of hemorrhage. The question is, can cirrhotic patients tolerate an operation of this magnitude when it is performed as an emergency in the face of bleeding? To answer this question, we have conducted prospective studies of emergency PCS (EPCS) over the past 47 years, as follows: (1) an unrandomized study of 400 unselected patients who underwent EPCS; (2) a RCT of EPCS versus emergency medical therapy involving 43 patients at our Veterans Administration Hospital; (3) an unrandomized study of 94 unselected, consecutive patients with Child's class C cirrhosis; (4) a RCT of portacaval shunt versus endoscopic sclerotherapy in 518 unselected patients bleeding from gastric varices; (5) an unrandomized study in 12 patients with uncontrollable bleeding from portal hypertensive gastropathy; (6) a NIH grant supported RCT of EPCS versus emergency endoscopic sclerotherapy (EST) that enrolled 211 patients who have had more than 10 years of follow-up or until death; and (7) a NIH grant supported RCT of TIPS versus EPCS that enrolled 154 patients who have been followed up for 5-10 years (Orloff, 1967; Orloff et al., 1980; Orloff et al., 1992; Orloff et al., 1994; Orloff et al., 1995a; Orloff et al., 2009a; Orloff et al., 2009b; Orloff et al., 2011a; Orloff et al., 2011b; Orloff et al., 2010; Orloff et al., 2011c; Orloff et al., 2011d; Orloff et al, 2011e; Orloff et al., 2011f; Orloff et al., 2011g; Orloff et al., 2011h; Orloff et al., 2011i; Orloff \& Bell, 1983; Bell, et al., 1981; Orloff, 1968; Orloff, 1969; Orloff et al., 1974; Orloff et al., 1975; Orloff \& Bell, 1986; Orloff et al., 1995b; Orloff et al., 1997) . The unique features of our studies that, together, make them different from other reported investigations are as follows: (1) EPCS was undertaken within $24 \mathrm{~h}$ of initial contact of the patient with our institution in one study and within $8 \mathrm{~h}$ in the other six studies; (2) the patients were unselected, which means that all patients with bleeding varices, regardless of their condition ("all comers"), were entered in the studies and treated; (3) the studies were prospective, which means that the patients were managed according to a well-defined and consistently applied protocol, and specific data were collected at the time of diagnosis, treatment, and follow-up; and (4) the patients were followed up monthly for the first year and every 3 months thereafter for life, such that the $1-, 5-$, and 10 -year follow-up rates were 100,98 , and $97 \%$, respectively. A total of 1,432 patients have been involved in these studies.

\section{Portal-systemic encephalopathy in our RCT of endoscopic sclerotherapy versus emergency portal shunt}

\subsection{Quantitation of PSE}

This recently published RCT is representative of all of our studies (Orloff et al., 2009a; Orloff et al., 2009b). PSE was quantitated during hospitalizations and at each clinic visit by grading 4 variously weighted components on a scale of 0 to 4 : (1) mental state, (2) asterixis, (3) number connection test, and (4) arterial blood ammonia. A PSE Index was calculated according to the method of Conn et al. (Conn \& Lieberthal, 1978) in which the scores of the 4 components were added to yield a PSE Sum, and then divided by the maximum possible PSE Sum. Mental state was given a weight of 3 and the other components a weight of 1 . To increase objectivity, a senior faculty gastroenterologist who was not otherwise involved in the BEV study evaluated each patient for PSE during the clinic visits. The gastroenterologist was "blinded" in that he was not told what therapy the patient had received. 
The definition of PSE was based on any one of the following criteria: (1) classical signs of altered mental status on physical examination performed by an experienced faculty physician; (2) classical signs of altered mental status described by outside physicians, close relatives of the patient, or the patient himself; (3) a high PSE Index of 0.33 or greater. Electroencephalography was not included in the evaluation because it was considered cumbersome, costly, and impractical given the numerous programmed and unprogrammed outpatient clinic and emergency department visits made by the patients. Patients were classified as having recurrent PSE when they had 2 or more episodes of PSE after primary therapy.

\subsection{Incidence of PSE}

Patients who were discharged from the hospital and survived more than 30 days after entry in the study numbered 93 in the EST group and 89 in the EPCS group. Calculations of the incidence and manifestations of recurrent PSE are based on this population. Deaths on or before 30 days were considered indeterminate and were unrelated to PSE. Dietary protein tolerance up to $80 \mathrm{~g}$ per day was observed in all patients before discharge. A 60-g protein restriction was prescribed upon discharge. Table 1 and Fig. 1 show data on this group of patients. Patients who developed recurrent PSE after discharge from the initial hospital admission numbered 33 or $35 \%$ in the EST group and 13 or $15 \%$ in the EPCS group. The difference was highly significant with a P value of 0.001 .

\begin{tabular}{|c|c|c|c|}
\hline & $\begin{array}{l}\text { EST } \\
(\mathrm{n}=93)\end{array}$ & $\begin{array}{l}\text { EPCS } \\
(\mathrm{n}=89)\end{array}$ & $\begin{array}{l}\mathrm{p} \\
\text { Value }\end{array}$ \\
\hline Incidence of recurrent PSE - n (\%) & $33(35)$ & $13(15)$ & $0.001^{*}$ \\
\hline Incidence of transient PSE - n (\%) & $3(3)$ & $3(3)$ & 1.0 \\
\hline $\begin{array}{l}\text { Length of survival: } \\
\text { Total days } \\
\text { Total years } \\
\text { Total days per patient } \\
\text { Total years per patient }\end{array}$ & $\begin{array}{l}133,243 \\
364.8 \\
1432.7 \\
3.9\end{array}$ & $\begin{array}{l}266,169 \\
728.7 \\
2990.7 \\
8.2\end{array}$ & $<0.001^{*}$ \\
\hline \begin{tabular}{|l} 
Episodes of recurrent PSE \\
Total episodes $-\mathrm{n}$ (n/person) \\
Episodes per year of follow-up \\
Interval between episodes (years) \\
\end{tabular} & $\begin{array}{l}179(1.92) \\
0.49 \\
2.03\end{array}$ & $\begin{array}{l}94(1.06) \\
0.13 \\
7.74 \\
\end{array}$ & $0.003^{*}$ \\
\hline $\begin{array}{l}\text { Hospital readmissions for recurrent PSE } \\
\text { Total readmissions - } \mathrm{n} \text { (n/ person) } \\
\text { Readmissions per year of follow-up } \\
\text { Interval between readmissions (years) } \\
\end{array}$ & $\begin{array}{l}146(1.57) \\
0.40 \\
2.50 \\
\end{array}$ & $\begin{array}{l}87(0.98) \\
0.12 \\
8.38 \\
\end{array}$ & $0.003^{*}$ \\
\hline $\begin{array}{l}\text { Cause of recurrent PSE episodes - n (\%) } \\
\text { Dietary protein indiscretion } \\
\text { UGI bleeding } \\
\text { Infection } \\
\text { Alcoholism } \\
\text { Uncontrolled diabetes } \\
\text { Hepatic failure } \\
\text { Other }\end{array}$ & $\begin{array}{l}75(42) \\
57(32) \\
18(10) \\
28(16) \\
2(1) \\
5(3) \\
7(4)\end{array}$ & $\begin{array}{l}60(64) \\
8(9) \\
12(13) \\
4(4) \\
11(12) \\
0(0) \\
5(5)\end{array}$ & $<0.001^{*}$ \\
\hline
\end{tabular}




\begin{tabular}{|l|l|l|l|}
\hline Timing of first episode of recurrent PSE - n (\%) & $17(52)$ & $8(62)$ & 0.30 \\
First 6 months & $6(18)$ & $1(8)$ & \\
Second 6 months & $23(70)$ & $9(69)$ & \\
Year-1 & $4(12)$ & $3(23)$ & \\
Year-2 & $2(6)$ & $0(0)$ & \\
Year-3 & $0(0)$ & $0(0)$ & \\
Year-4 & $1(3)$ & $0(0)$ & \\
Year-5 & $3(9)$ & $1(8)$ & \\
Year $>5$ & $24(15)$ & $23(24)$ & \\
\hline Timing of all episodes of recurrent PSE - n (\%) & $31(19)$ & $8(8)$ & \\
First 6 months & $55(34)$ & $31(33)$ & \\
Second 6 months & $46(28)$ & $32(34)$ & \\
Year-1 & $18(11)$ & $11(12)$ & \\
Year-2 & $15(9)$ & $14(15)$ & \\
Year-3 & $4(2)$ & $1(1)$ & \\
Year-4 & $26(16)$ & $6(6)$ & \\
Year-5 & & & \\
Year $>5$ & & & \\
\hline Relationship of recurrent PSE to survival - & $2.90(1.5,4.74)$ & $5.18(1.26$, Inf) & \\
Years (median, 95\% CI) & $1.23(0.94,3.17)$ & $4.14(1.17$, Inf) & \\
Patient with recurrent PSE: & $3.26(2.00,4.34)$ & $10.37(6.19$, Inf) & \\
Overall survival & $0.042^{*}$ & $0.001^{*}$ & \\
Survival after first PSE & $19(20)$ & $12(13)$ & \\
Patients free of recurrent PSE: & & & \\
Overall survival & $15(79)$ & \\
P value - Recurrent PSE vs. no PSE & & \\
\hline High PSE Index $-\mathrm{n}$ (\%) & & \\
Patients with PSE Index $\geq 0.33$ & $(33)$ & \\
Patients with PSE Index $\geq 0.33$ who & & \\
had recurrent clinical PSE & & \\
\hline
\end{tabular}

* statistically significant difference

Table 1. Recurrent PSE in Patients Who Survived $>30$ Days and Were Discharged from the Hospital

The 93 early survivors in the EST group lived for a collective total of 364.8 years, while the 89 early survivors who underwent EPCS lived a collective total of 728.7 years, twice as long as the EST patients $(p<0.001)$. The patients with recurrent PSE in the EST group had a collective total of 179 episodes of PSE and were readmitted to the hospital 146 times for treatment of PSE. In contrast, the patients with recurrent PSE following EPCS, experienced 94 episodes and 87 hospital readmissions. The calculated yearly frequency of PSE episodes was $0.49 / \mathrm{yr}$ in the EST group and $0.13 / \mathrm{yr}$ in the EPCS group, and the calculated hospital readmission rate was $0.40 / \mathrm{yr}$ in the EST patients and only $0.12 / \mathrm{yr}$ in the EPCS patients $(p=0.003)$. Expressed as per-patient average, patients in the EST group were hospitalized for recurrent PSE every 2.50 years, while patients who were treated by EPCS required hospitalization for recurrent PSE every 8.38 years $(\mathrm{p}=0.003)$. 


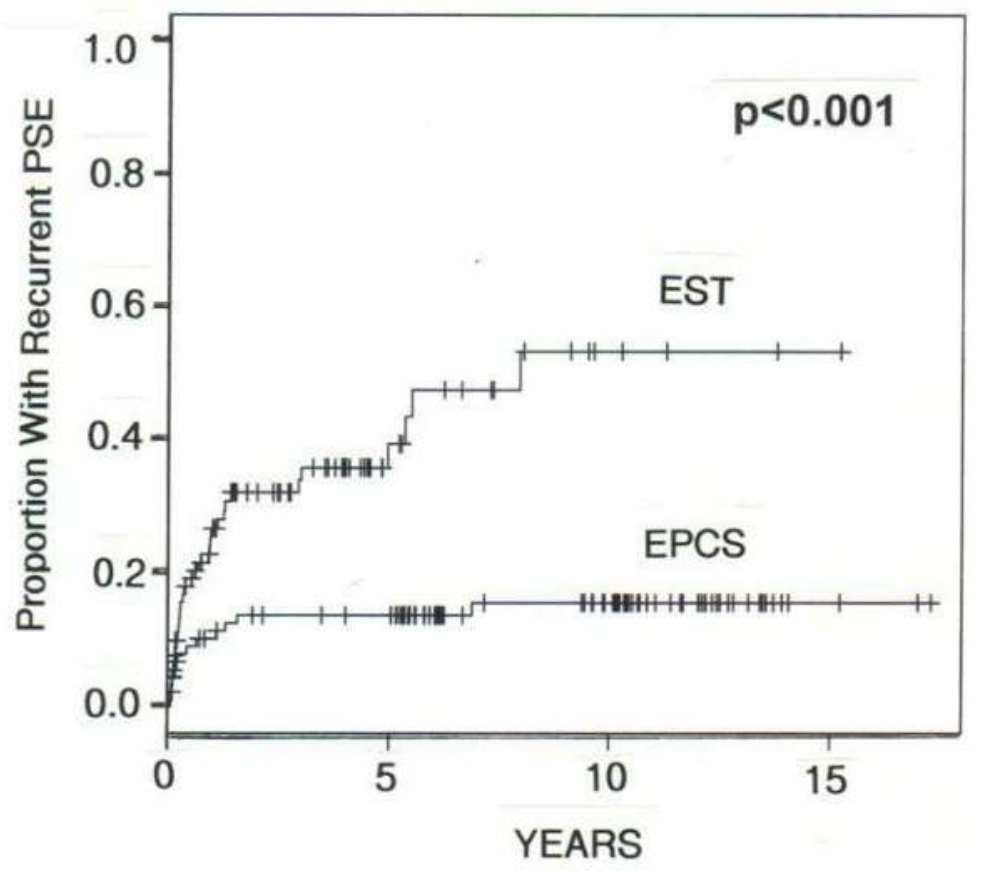

Fig. 1. Incidence and timing of recurrent PSE in patients who were randomized to EST $(n=93)$ or EPCS $(n=89)$ and survived $>30$ days and were discharged from the hospital.

\subsection{Cause of recurrent PSE}

Dietary indiscretion with regard to protein restriction was the most frequent cause of recurrent PSE in both groups more so in the patients treated by EPCS. Portal hypertensionrelated UGI bleeding, usually from esophageal varices, was the main cause of recurrent PSE in $32 \%$ of the episodes experienced in patients treated by EST, and was a contributing cause in an additional $18 \%$. Gastrointestinal bleeding was infrequently responsible for PSE in patients who underwent EPCS $(\mathrm{p}<0.001)$. Thus, gastrointestinal bleeding played a role in 57 episodes of PSE in the EST group, compared to 8 episodes in the EPCS group, and undoubtedly was a major factor in the higher incidence of recurrent PSE following EST. Other conditions responsible for at least $10 \%$ of PSE episodes were infection, alcoholism, and uncontrolled diabetes.

\subsection{Relationship of recurrent PSE to survival}

In the EST group, patients with recurrent PSE lived a median 2.90 years while those who remained free of PSE lived a median 3.6 years, a longer period of time. This difference was significant $(p=0.042)$ with a hazard ratio of death due to recurrent PSE of 1.60 (95\% confidence interval 1.01, 2.56). It is not possible in the EST group to determine the effect of PSE on survival because of other factors, particularly recurrent BEV, which influenced survival. 
In the EPCS group, patients who remained free of PSE lived a median 10.37 years, significantly longer than those with recurrent PSE who survived a median 5.18 years. The difference was significant $(p=0.001)$. It is tempting to attribute the longer survival to freedom from PSE, but the many factors that affect survival make it inappropriate to single out PSE as the main determinant of life or death.

The results with regard to PSE of our randomized controlled trial are contrary to conventional beliefs about both portacaval shunt and endoscopic sclerotherapy. The incidence of recurrent PSE during long-term follow-up of unselected patients treated by EPCS was only $15 \%$, which was significantly lower than the $35 \%$ incidence of PSE following emergency and long-term EST. Moreover, every aspect of PSE was less severe following EPCS than after EST. The number of PSE episodes was fewer (94 vs. 179), the number of hospital readmissions for PSE was fewer ( 87 vs. 146), the calculated yearly frequency of PSE was lower, and the calculated per-patient average hospitalization for PSE was less frequent (once every $8.38 \mathrm{yr}$ vs. once every $2.50 \mathrm{yr}$ ) in the EPCS group than in the EST patients.

A number of factors appear to have played a role in causing PSE, but two of these factors were predominant. The first was dietary protein indiscretion. Despite concerted, repeated and often successful efforts to educate patients on limiting dietary protein intake to $60 \mathrm{~g}$ per day, dietary protein indiscretion was responsible for 75 of the 179 episodes of PSE in the EST group and 60 of the 94 episodes of PSE in the EPCS group. The second causative factor was recurrent variceal bleeding which was directly responsible for $32 \%$ of the episodes of PSE in patients treated by EST, and was a major contributing cause in an additional $18 \%$ of the episodes. In contrast, UGI bleeding at best may have been responsible for only 8 of the 94 episodes of PSE in patients who had EPCS. It appears highly likely that the higher incidence of PSE following EST compared to EPCS was due to the failure of EST to achieve long-term control of BEV. It is noteworthy that resumption of alcoholism may have played a role in only $12 \%$ of the episodes of PSE. These results demonstrate that a low incidence of PSE is possible when patients are free of recurrent UGI bleeding, abstain from alcohol, and comply with a diet of moderate protein restriction.

\section{Portal-systemic encephalopathy in our RCT of TIPS versus emergency portacaval shunt}

We have completed a RCT of emergency TIPS versus EPCS that enrolled 154 unselected consecutive patients who have been followed up for 5 to 10 years. The results of this RCT have been submitted for publication (Orloff et al., 2011h; Orloff et al., 2011j). Transjugular intrahepatic portosystemic shunt, or TIPS, is a side-to-side portacaval shunt performed radiologically by a percutaneous approach. It is the most widely used form of portal decompression and is used to control BEV when other measures, such as endoscopic treatment and pharmacologic therapy, have failed. The major shortcomings of TIPS reported in numerous studies have been a high incidence of occlusion of the shunt and the frequent occurrence of PSE.

In our RCT, regular follow-up to determine patency of the TIPS and EPCS revealed stenosis or occlusion of the TIPS in $84 \%$ of this group of patients. Patients treated by TIPS had a mean 2.1 episodes of TIPS stenosis or occlusion. Revision of the TIPS by balloon angioplasty or insertion of one or more additional stents was performed in $63 \%$ of the patients with TIPS 
malfunction. The revisions failed in $80 \%$ of the patients. The consequences of TIPS malfunction were recurrent BEV and PSE. Durability of TIPS was disappointing. In marked contrast, EPCS remained permanently patent in $97 \%$ of the patients in that groups, as a result of which there was permanent prevention of recurrent BEV and a significantly lower incidence of PSE. In the overall, 61\% of the patients treated by TIPS developed recurrent PSE, compared to $21 \%$ of the patients treated by EPCS. The three-fold greater incidence of recurrent PSE in the TIPS group was highly significant $(\mathrm{p}<0.001)$.

In both of our recently reported RCTs, EPCS was a total shunt that involved a direct anastomosis between the portal vein and inferior vena cava. EPCS permanently controlled variceal bleeding, resulted in long-term survival that was substantially greater than that obtained by EST, and was followed by a relatively low rate of PSE that was less than onehalf the rate associated with EST. How do we account for the low incidence of PSE? We believe that a number of factors played an important role in the results achieved by EPCS in our study. First, and most important, EPCS was uniformly successful in preventing recurrent $\mathrm{BEV}$, a frequent cause of PSE. Second, hepatic function improved and stabilized in a substantial majority of patients as a result of both freedom from bleeding and abstinence from alcohol, which was permanent in $62 \%$ of the patients. Third, follow-up evaluation and support was rigorous, frequent and lifelong in all patients. Fourth, follow-up included regular counseling by a dietitian on restriction of dietary protein intake to $60 \mathrm{~g} /$ day, an amount that is quite ample for nutrition and is compatible with an appetizing diet. A high level of patient compliance was obtained by repeated education about the importance of moderate protein restriction. Fifth, long-term patency and function of the portacaval shunt was obtained in $98 \%$ of patients. No one of these factors alone can account for the low incidence of PSE, but together they resulted in a rate of PSE that was less than one-half the rate associated with EST.

\section{Conclusions}

In these prospective randomized controlled trials of emergency treatment of acute bleeding esophageal or gastric varices in 4 separate studies involving 628 unselected, consecutive patients with cirrhosis of all grades of severity, EPCS was followed by a 15-21\% incidence of recurrent PSE, which was significantly lower than the 35\% incidence of PSE that followed emergency and long-term EST and the $61 \%$ incidence associated with TIPS. These results contradict the widespread belief that portal-systemic shunts are associated with a high incidence of PSE. Moreover, these results call into question the widespread practice of using portal-systemic shunt mainly or only as salvage for failure of endoscopic and pharmacologic therapy because of the belief that the superior control of variceal bleeding by surgery is offset by life-threatening PSE.

\section{Acknowledgement}

This work was supported by NIH grants A3084, A5919, AM07315, AM07511, AM1228, AM19875, AM12280, DK41920, and a grant from the Surgical Education and Research Foundation [501(c)(3)].

Registration: clinicaltrials.gov NCT00690027 


\section{References}

Bell, R.H. Jr.; Hyde, P.V.B.; Skivolocki, W.P.; Brimm, J.E., \& Orloff, M.J. (1981) Prospective study of portasystemic encephalopathy after emergency portacaval shunt for bleeding varices. American Journal of Surgery 142(1), 144-150.

Bender, A.S.; \& Norenberg, M.D. (1996) Effects of ammonia on L-glutamate uptake in cultured astrocytes. Neurochemistry Research 21(5), 567-573.

Bengtsson, F.; Nobin, A.; Falck, B.; Gage, F.H.; \& Jeppsson, B. (1980) Portacaval shunt in the rat: Selective alterations in behaviour and brain serotonin. Pharmacology Biochemistry and Behavior 24(6), 1611-1616.

Bergeron, M.; Reader, T.A.; Pomier Layrargues, G.; \& Butterworth, R.F. (1989) Monoamines and metabolites in autopsied brain tissue from cirrhotic patients with hepatic encephalopathy. Neurochemistry Research 14(9), 853-859.

Bergeron, M.; Swain, M.S.; Reader, T.A.; Grondin, L.; \& Butterworth, R.F. (1990) Effect of ammonia on brain serotonin metabolism in relation to function in the portacavalshunted rat. Journal of Neurochemistry 55(1), 222-229.

Bergeron, M.; Swain, M.S.; Reader, T.A.; \& Butterworth, R.F. (1995) Regional alterations of dopamine and its metabolites in rat brain following portacaval anastomosis. Neurochemistry Research 20(1), 79-86.

Bismuth, M.; Funakoshi, N.; Cadranel, J-F.; \& Blanc, P. (2011) Hepatic encephalopathy: from pathophysiology to therapeutic management. European Journal of Gastroenterology and Hepatology 23(1), 8-22.

Bornman, P.C.; Krige, J.E.; \& Terblanche, J. (1994) Management of esophageal varices. Lancet 343(8905), 1079-1084.

Brown, R.L.; Gibson, J.A.; Sladen, G.E.; Hicks, B.; \& Dawson, A.M. (1974) Effects of lactulose and other laxatives on ileal and colonic $\mathrm{pH}$ as measured by a radiotelemetry device. Gut 15(12), 999-1004.

Burroughs, A.K.; Mezzanotte, G.; Phillips, A.; McCormick, P.A.; \& McIntyre, N. (1989) Cirrhotics with variceal hemorrhage: the importance of the time interval between admission and the start of analysis for survival and rebleeding rates. Hepatology 9(6), 801-807.

Butterworth, R.F.; Wells, J.; \& Pomier Layrargues, G. (1995) Detection of benzodiazepines in hepatic encephalopathy: reply. Hepatology 21(2), 604-605.

Conn, H.O., \& Lieberthal, M.M. (1978) The hepatic coma syndromes and lactulose. Williams \& Wilkins, Baltimore.

Cordoba, J.; \& Blei, A.T. (1997) Treatment of hepatic encephalopathy. Am J Gastroenterol 92, 1429-1439.

D'Amico, G.; Pagliaro, L.; \& Bosch, J. (1995) The treatment of portal hypertension: a metaanalytic review. Hepatology 22(1), 332-354.

Dashti, H.; Jeppsson, B., Hägerstrand, I.; Hultberg, B.; Srinivas, U., Abdulla, M., \& Bengmark, S. (1989) Thioacetamide- and carbon tetrachloride-induced liver cirrhosis. European Surgical Research 21(2), 83-91.

Desjardins, P.; Bandeira, P.; Raghavendra Rao, V.L.; Ledoux, S.; \& Butterworth, R.F. (1997) Increased expression of the peripheral-type benzodiazepine receptor-isoquinoline carboxamide binding protein mRNA brain following portacaval anastomosis. Brain Research 758(1-2), 255-258.

Eck, N.V. (1877). Kvoprosu opereviazke vorotnoi veni: Predvaritelnoye soobschjenie (Concerning ligation of the vena porta: Preliminary notification). Voen Med Zh 130, 1-2. 
Ferenci, P.; Herneth, A.; \& Steindl, P. (1996) Newer approaches to therapy of hepatic encephalopathy. Seminars in Liver Disease 16(3), 329-338.

Fitzhugh, O.G., \& Nelson, A.A. (1948) Liver tumors in rats fed thiourea or thioacetamide. Science 108(2814), 626-628.

Gabuzda, D., Jr.; Philips, G.G., \& Davidson, C.S. (1952) Reversible toxic manifestations in 2 patients with cirrhosis of the liver given cation-exchange resins. $N$ Engl J Med 246(4), 124-130.

Giguère, J-F.; Hamel, E.; \& Butterworth, R.F. (1992) Increased densities of binding sites for the "peripheral-type" benzodiazepine receptor ligand ${ }^{3} \mathrm{H}-\mathrm{PK} 11195$ in rat brain following portacaval anastomosis. Brain Research 585(1-2), 295-298.

Graham, D.Y.; \& Smith H. (1981) The course of patients after variceal hemorrhage. Gastroenterology 80(4), 800-809.

Gyr, K., Meier, R.; Häussler, J.; Boulétreau, P.; Fleig, W.E.; Gatta, A.; Holstege, A.; PomierLayrargues, G.; Schalm, S.W.; Groeneweg, M.; Scollo-Lavizzari, G.; Ventura E.; Zeneroli, M.L.; Williams, R.; Yoo, Y.; \& Amrein, R. (1996) Evaluation of the efficacy and safety of flumazenil in the treatment of portal systemic encephalopathy: a double blind, randomised, placebo controlled multicentre study. Gut 39(2), 319-324.

Hahn, M., Massen, V.N., Nenski, M., \& Pavlov, I.P. (1893). Die Eck' sche Fistel zwischen der unteren Hohlvene und der Pfortader und ihre Folgen Fur den Organismus, Arch Exp Pathol Pharmakol 32, 161-210.

Hazell, A.S.; Desjardins, P.; \& Butterworth, R.F. (1999a) Chronic exposure of rat primary astrocyte cultures to manganese results in increased binding site for 'peripheraltype' benzodiazepine receptor ligand 'H-PK 11195. Neuroscience Letters 271(1), 5-8.

Hazell, A.S.; Desjardins, P.; Butterworth, R.F. (1999b) Increased expression of glyceraldehyde-3-phosphate dehydrogenase in cultured astrocytes following exposure to manganese. Neurochemistry International 35(1), 11-17.

Hindfelt, B.; Plum, F.; \& Duffy, T.E. (1977) Effect of acute ammonia intoxication on cerebral metabolism in rats with portacaval shunts. Journal of Clinical Investigation 59(3), 386396.

Khan, S.; Tudur Smith, C.; Williamson, P; \& Sutton, R. (2006) Portosystemic shunts versus endoscopic therapy for variceal rebleeding in patients with cirrhosis. Cochrane Database of Systematic Reviews, Issue 1. Art. No. CD000553. doi:10.1002/14651858. CD000553. Pub 2.

Kircheis, G.; Nilius, R.; Held, C.; Berndt, H.; Buchner, M.; Görtelmeyer, R.; Hendricks, R.; Krüger B.; Kuklinski, B.; Meister, H.; Otto, H.J.; Rink, C.; Rösch, W.; Stauch, S. (1997) Therapeutic efficacy of L-ornithine-L-aspartate infusions in patients with cirrhosis and hepatic encephalopathy: Results of a placebo-controlled, double-blind study. Hepatology 25(6), 1351-1360.

Knecht, K.; Michalak, A.; Rose, C., Rothstein, J.D., Butterworth, R.F. (1997) Decreased glutamate transporter (GLT-1) expression in frontal cortex of rats with acute liver failure. Neuroscience Letters 229(3), 201-203.

Lai, J.C.K.; \& Cooper, A.J.L. (1986) Brain a-Ketoglutarate dehydrogenase complex: Kinetic properties, regional distribution and effects of inhibitors. Journal of Neurochemistry 47(5), 1376-1386.

Lavoie, J.; Pomier Layrargues, G.; Butterworth, R.F. (1990) Increased densities of peripheraltype benzodiazepine receptors in brain autopsy samples from cirrhotic patients with hepatic encephalopathy. Hepatology 11(5), 874-878. 
Lockwood A.M.; McDonald, J.M.; Rieman, R.E.; Gelbard, A.S.; Laughlin, J.S.; Duff, T.E.; Plum, F. (1979) The dynamics of ammonia metabolism in man: Effects of liver disease and hyperammonemia. Journal of Clinical Investigation 63(3), 449-640.

López-Novoa, J.M. (1988) Pathophysiological features of the carbon tetrachloride/phenobarbital model of experimental liver cirrhosis in rats. In: The Kidney in Liver Disease, Epstein, M.D., ed., pp. 309-327, Williams \& Wilkins, Baltimore.

Maddison, J.E.; Watson, W.E.J.; Dodd, P.R.; Johnston, G.A.R. (1991) Alterations in cortical $\left[{ }^{3} \mathrm{H}\right]$ kainite and $\mathrm{a}-\left[{ }^{3} \mathrm{H}\right]$ amino-3-hydroxy-5-methyl-isoxazolepropionic acid binding in a spontaneous canine model of chronic hepatic encephalopathy. Journal of Neurochemistry 56(6), 1881-1888.

Mikkelsen, W.P. (1974) Therapeutic portacaval shunt. Preliminary data on controlled trial and morbid effects of acute hyaline necrosis. Arch Surg 108(3), 302-305.

Mousseau, D.D.; Perney, P.; Pomier Layrargues, G.; Butterworth, R.F. (1993) Selective loss of pallidal dopamine $\mathrm{D}_{2}$ receptor density in hepatic encephalopathy. Neuroscience Letters 162(1-2), 192-196.

Mousseau, D.D.; Baker, G.B.; Butterworth, R.F. (1997) Increased density of catalytic sites and expression of brain monoamine oxidase $\mathrm{A}$ in humans with hepatic encephalopathy. J Neurochem 68(3), 1200-1208.

Munoz, S.J. (2008) Hepatic encephalopathy. Medical Clinics of North America 92(4), 795-812.

Nuber, R.; Teutsch, H.F.; Sasse, D. (1980) Metabolic zonation in thioacetamide-induced liver cirrhosis. Histochemistry 69(3), 277-288.

Orloff, M.J.; Wall, M.H., Hickman, E.G.; Neesby, T. (1963) Influence of stomal size of portacaval shunts on peripheral blood ammonia levels. Ann Surg 158(2), 172-181.

Orloff, M.J. (1967) Emergency portacaval shunt: A comparative study of shunt, varix ligation and nonsurgical treatment of bleeding esophageal varices unselected patients with cirrhosis. Ann Surg 166(3), 456-478.

Orloff, M.J. (1968) Emergency treatment of bleeding esophageal varices. In: The Therapy of Portal Hypertension, N.G. Markoff (ed.), George Thieme Verlag, Stuttgart, pp. 211219.

Orloff, M.J. (1969) Emergency treatment of bleeding esophageal varices in alcoholic cirrhosis. In: Biochemical and Clinical Aspects of Alcohol Metabolism, V.M. Sardesai (ed.), Charles C. Thomas, Springfield, IL, 288-297.

Orloff, M.J.; Chandler, J.G.; Charters, A.C. III; Condon, J.K.; Grambort, D.E.; Modafferi, T.R.; Levin, S.E. (1974) Emergency portacaval shunt treatment for bleeding esophageal varices. Prospective study in unselected patients with alcoholic cirrhosis. Arch Surg 108(3), 293-299.

Orloff, M.J.; Charters, A.C.; Chandler, J.G., Condon, J.K.; Grambort, D.E.; Modafferi T.R.; Levin, S.E.; Brown, N.B.; Sviokla, S.C.; Knox, D.G. (1975). Portacaval shunt as emergency procedure in unselected patients with alcoholic cirrhosis. Surg Gynecol Obstet 141(1), 59-68.

Orloff, M.J.; Duguay, L.R.; Kosta, L.D. (1977) Criteria for selection of patients for emergency portacaval shunt. Am J Surg 134(1), 146-152.

Orloff, M.J.; Bell, R.H. Jr.; Hyde, P.V.; Skivolocki, W.P. (1980) Long-term results of emergency portacaval shunt for bleeding esophageal varices in unselected patients with alcoholic cirrhosis. Ann Surg, 192(3), 325-340.

Orloff, M.J.; Bell, R.H. Jr. (1983) Improved survival of unselected cirrhotic patients with bleeding esophageal varices treated by emergency portacaval shunt. Gastroenterology, 84, 1388. 
Orloff, M.J.; Bell, R.H. Jr. (1986) Long-term survival after emergency portacaval shunting for bleeding varices in patients with alcoholic cirrhosis. Amer J Surg 151(1), 176-183.

Orloff, M.J.; Orloff, M.S.; Rambotti, M.; Girard, B. (1992) Is portal-systemic shunt worthwhile in Child's class $C$ cirrhosis? Long-term results of emergency shunt in 94 patients with bleeding varices. Ann Surg 216(3), 256-268.

Orloff, M.J.; Bell, R.H. Jr.; Orloff, M.S.; Hardison, W.G.M., Greenburg, A.G. (1994) Prospective randomized trial of emergency portacaval shunt and emergency medical therapy in unselected cirrhotic patients with bleeding varices. Hepatology $20(4$, pt 1$), 863-872$.

Orloff, M.J.; Orloff, M.S.; Orloff, S.L.; Rambotti, M. (1995a) Three decades of experience with emergency portacaval shunt for acutely bleeding esophageal varices in 400 unselected patients with cirrhosis of the liver. Journal of the American College of Surgeons 180(3), 257-272.

Orloff, M.J.; Orloff, M.S.; Orloff, S.L.; Haynes, K.S. (1995b) Treatment of bleeding from portal hypertensive gastropathy by portacaval shunt. Hepatology 21(4), 1011-1017.

Orloff, M.J.; Orloff, M.S.; Orloff, S.L.; Girard, B. (1997) Long-term results of portacaval shunt for bleeding gastric varices in 224 patients with cirrhosis. Gastroenterology 112(4), A3194.

Orloff, M.J.; Isenberg, J.I.; Wheeler, H.O.; Haynes, K.S.; Jinich-Brook, H.; Rapier, R.; Vaida, F.; Hye, R.J. (2009a) Randomized trial of emergency endoscopic sclerotherapy versus emergency portacaval shunt for acutely bleeding esophageal varices in cirrhosis. Journal of the American College of Surgeons 209(1), 25-40.

Orloff, M.J.; Isenberg, J.I.; Wheeler, H.O.; Haynes, K.S.; Jinich-Brook, H.; Rapier, R.; Vaida F, Hye RJ. (2009b) Portal-systemic encephalopathy in a randomized controlled trial of endoscopic sclerotherapy versus emergency portacaval shunt treatment of acutely bleeding esophageal varices in cirrhosis. Ann Surg 250(4), 598-610.

Orloff, M.J.; Isenberg, J.I.; Wheeler, H.O.; Haynes, K.S.; Jinich-Brook, H.; Rapier, R.; Vaida, F.; Hye, R.J., \& Orloff, S.L. (2010) Liver transplantation in a randomized controlled trial of emergency treatment of acutely bleeding esophageal varices in cirrhosis. Transplantation Proceedings 42(10), 4101-4108.

Orloff, M.J.; Isenberg, J.I.; Wheeler, H.O.; Haynes, K.S.; Jinich-Brook, H.; Rapier, R.; Vaida, F.; Hye, R.J. (2011a) Emergency portacaval shunt versus rescue portacaval shunt in a randomized controlled trial of emergency treatment of acutely bleeding esophageal varices in cirrhosis - part 3. Journal of Gastrointestinal Surgery 14(11), 1782-1795.

Orloff, M.J.; Isenberg, J.I.; Wheeler, H.O.; Haynes, K.S.; Jinich-Brook, H.; Rapier, R.C.; Vaida, F.N.; Hye, R.J.; Orloff, S.L. (2011b) Direct costs of care in a randomized controlled trial of endoscopic sclerotherapy versus emergency portacaval shunt for bleeding esophageal varices in cirrhosis - part 4. Journal of Gastrointestinal Surgery 15(1), 3847.

Orloff, M.J.; Isenberg, J.I.; Wheeler, H.O.; Haynes, K.S.; Jinich-Brook, H.; Rapier, R.; Vaida, F.; Hye, R.J.; Orloff, S.L. (2011c) Hepatocellular carcinoma in a randomized controlled trial of emergency treatment of bleeding esophageal varices in cirrhosis. Am J Surg, in press.

Orloff, M.J.; Isenberg, J.I.; Wheeler, H.O.; Haynes, K.S.; Jinich-Brook, H.; Rapier, R.; Vaida, F.; Hye, R.J.; Orloff, S.L. (2011d) Alcoholic versus nonalcoholic cirrhosis in a randomized controlled trial of emergency treatment of acutely bleeding esophageal varices. Journal of Surgical Research; in press. 
Orloff, M.J.; Isenberg, J.I.; Wheeler, H.O.; Haynes, K.S.; Jinich-Brook, H.; Rapier, R.; Vaida, F.; Hye, R.J.; Max, W. (2011e) Economic cost of mortality and morbidity in a randomized controlled trial of emergency therapy of bleeding esophageal varices in cirrhosis. Hepatology, in press.

Orloff, M.J.; Vaida, F; Isenberg, J.I.; Wheeler, H.O.; Haynes, K.S.; Jinich-Brook, H.; Rapier, R.; Hye, R.J.; Orloff, S.L. (2011f) Child-Turcotte score versus MELD for prognosis in a randomized controlled trial of emergency treatment of bleeding esophageal varices in cirrhosis. J Hepatology, in press.

Orloff, M.J.; Isenberg, J.I.; Wheeler, H.O.; Haynes, K.S.; Jinich-Brook, H.; Rapier, R.; Vaida, F.; Hye, R.J.; Orloff, S.L. (2011g) Disability index in a randomized controlled trial of sclerotherapy versus portacaval shunt for bleeding varices in cirrhosis. Amer J Surg, submitted for publication.

Orloff, M.J.; Vaida, F.; Wheeler, H.O.; Isenberg, J.I.; Haynes, K.S.; Girard., B. (2011h) Randomized controlled trial of endoscopic therapy versus portacaval shunt treatment of bleeding gastric varices in cirrhosis. Journal of Gastrointestinal Surgery, in press.

Orloff, M.J.; Vaida, F., Roberts, A., Rose, S., Haynes, K., Hye, R.J.; Isenberg, J. (2011i) Randomized controlled trial of emergency transjugular Intrahepatic portosystemic shunt versus emergency portacaval shunt treatment of acute bleeding esophageal varices in cirrhosis. Journal of the American College of Surgery, in press.

Orloff, M.J., Vaida, F., Roberts, A.C., Rose, S.C., Haynes, K.S., Hye, R.J., \& Isenberg, J.I. (2011j). Portal-systemic encephalopathy in a randomized controlled trial of emergency transjugular intrahepatic portosystemic, shunt versus emergency portacaval shunt treatment of acute bleeding esophageal varices in cirrhosis. Submitted for publication.

Pavlov, I.P. (1893). On a modification of the Eck fistula between the portal vein and the inferior vena cava. Arch Sci Biol 2, 580-585.

Pomier Layrargues, G.; Giguère, J.F.; Lavoie, J.; Perney, P.; Gagnon, S.; D’Amour, M., Wells, J.; Butterworth, R.F. (1994) Flumazenil in cirrhotic patients in hepatic coma: a randomized double-blind placebo-controlled crossover trial. Hepatology 19(1), 3237.

Pomier Layrargues, G.; Spahr, L.; Butterworth, R.F. (1995) Increased manganese concentrations in pallidum of cirrhotic patients. Lancet 345(8951), 735.

Raghavendra Rao, V.L.; Audet, R.; Therrien, G.; Butterworth, R.F. (1994) Tissue-specific alterations of binding sites for peripheral-type benzodiazepine receptor ligand $\left[{ }^{3} \mathrm{H}\right] \mathrm{PK} 11195$ in rats following portacaval anastomosis. Digestive Disease and Science 39(5), 1055-1063.

Raghavendra Rao, V.L.; Audet, R.M.; Butterworth, R.F. (1995) Increased nitric oxide synthase activities and I-[3H]arginine uptake in brain following portacaval anastomosis. Journal of Neurochemistry 65(2), 677-681.

Raghavendra Rao, V.L.; Audet, R.M.; Butterworth, R.F. (1997a) Increased neuronal nitric oxide synthase expression in brain following portacaval anastomosis. Brain Research 765(1), 169-172.

Raghavendra Rao, V.L.; Audet, R.M.; Butterworth, R.F. (1997b) Portacaval shunting and hyperammonemia stimulate the uptake of $\mathrm{L}-{ }^{3} \mathrm{H}$-arginine but not of $\mathrm{L}^{-} \mathrm{H}-$ nitroarginine into rat brain synaptosomes. Journal of Neurochemistry 68(1), 337-343.

Raghavendra Rao, V.L.; Butterworth, R.F. (1998) Neuronal nitric oxide synthase and hepatic encephalopathy. Metabolic Brain Disease 13(3), 175-189. 
Rose, C.; Michalak, A.; Pannunzio, P.; Thierrien, G.; Quack, G.; Kircheis, G.; Butterworth, R.F. (1998) L-orthinine-L-aspartate in experimental portal-systemic encephalopathy: therapeutic efficacy and mechanism of action. Metabolic Brain Disorders 13(2), 147-157.

Sarfeh, J.J.; Rypins, E.B. (1994) Partial versus total portacaval shunt in alcoholic cirrhosis. Results of a prospective, randomized clinical trial. Ann Surg 219(4), 353-361.

Smith, J.L.; Graham, D.Y. (1982) Variceal hemorrhage: a critical evaluation of survival analysis. Gastroenterology 82(5), 968-973.

Sushma, S.; Dasarathy, S.; Tandon, R.K.; Jain, S.; Gupta, S.; Bhist, M.S. (1992) Sodium benzoate in the treatment of acute hepatic encephalopathy: a double-blind randomized trial. Hepatology 16(1), 138-144.

Swart, G.R.; van den Berg, J.W.O.; van Vuure, J.K.; Rietveld, T.; Wattimena, D.L.; Frenkel, M. (1989) Minimum protein requirements in liver cirrhosis determined by nitrogen balance measurements at three levels of protein intake. Clinical Nutrition 8(6), 329336.

Szerb, J.C., Butterworth, R.F. (1992) Effect of ammonium ions on synaptic transmission in the mammalian central nervous system. Progressive Neurobiology 39(2), 135-153.

Terblanche, J.; Burroughs, A.K.; Hobbs, K.E.F. (1989) Controversies in the management of bleeding oesophageal varices. N Engl J Med 320(21), 1393-1398.

Therrien, G.; Giguère, J-F.; Butterworth, R.F. (1991) Increased cerebrospinal fluid lactate reflects deterioration of neurological status in experimental portal-systemic encephalopathy. Metabolic Brain Disorders, 6(4), 225-231.

Tricklebank, M.D.; Smart, J.L.; Bloxam, D.L., et al. (1978) Effects of chronic experimental liver dysfunction and L-tryptophan on behavior in the rat. Pharmacology Biochemisry and Behavior 9(2), 181-189.

Weissenborn, K.; Ehrenheim, C.H.; Hori, A.; Kubicka, S.; Manns, M.P. (1995) Pallidal lesions in patients with liver cirrhosis: clinical and MRI evaluation. Metabolic Brain Disorders 10(3), 219-231.

Wolpert, E.; Phillips, S.F.; Summerskill, W.H.J. (1970) Ammonia production in the human colon. Effects of cleansing, neomycin and acetohydroxamic acid. $N$ Engl J Med 283(4), 159-164.

Yao, H.; Sadoshima, S.; Fujii, K.; Kusuda, K.; Ishitsuka, T.; Tamaki, K.; Fujishima, M. (1987) Cerebrospinal fluid lactate in patients with hepatic encephalopathy. European Neurology 27(3), 182-187.

Young, S.N.; Lai, S. (1980) CNS tryptamine metabolism in hepatic coma. Journal of Neural Transmission 47(3), 153-161.

Zervox, E.E.; Goode, S.E.; \& Rosemurgy, A.S. (1998) Immediate and long-term portal hemodynamic consequences of small-diameter H-graft portacaval shunt. Journal of Surgical Research 74(1), 71-75.

Zieve, L.; Doizaki, W.M.; Zieve, J. (1974) Synergism between mercaptans and ammonia or fatty acids in the production of coma: a possible role for mercaptans in the pathogenesis of hepatic coma. Journal of Laboratory and Clinical Medicine 83(1), 16-28.

Zieve, L. (1989) Role of toxins and synergism in hepatic encephalopathy. In: Hepatic Encephalopathy: Pathophysiology and Treatment. Butterworth, R.F., \& Pomier Layrargues, G., eds, pp. 141-156. Humana Press; Clifton, NJ. 


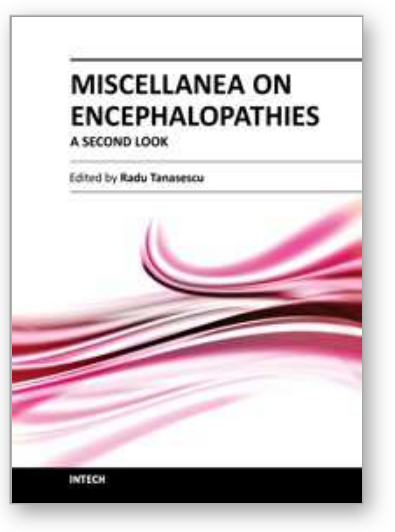

\author{
Miscellanea on Encephalopathies - A Second Look \\ Edited by Dr. Radu Tanasescu
}

ISBN 978-953-51-0558-9

Hard cover, 390 pages

Publisher InTech

Published online 25, April, 2012

Published in print edition April, 2012

The book project "Miscellanea on Encephalopathies-a second look" aims to cover some of the important aspects regarding metabolic, hypoxic, neoplasm- and drug-related encephalopathies, by transmitting valuable information filtered through the real life clinical and research experience of the authors.

\title{
How to reference
}

In order to correctly reference this scholarly work, feel free to copy and paste the following:

Marshall J. Orloff (2012). Portal-Systemic Encephalopathy in Emergency Treatment of Cirrhosis and Bleeding Esophageal Varices, Miscellanea on Encephalopathies - A Second Look, Dr. Radu Tanasescu (Ed.), ISBN: 978-953-51-0558-9, InTech, Available from: http://www.intechopen.com/books/miscellanea-onencephalopathies-a-second-look/portal-systemic-encephalopathy-following-treatment-of-bleeding-esophagealvarices-in-cirrhosis

\section{INTECH}

open science | open minds

\author{
InTech Europe \\ University Campus STeP Ri \\ Slavka Krautzeka 83/A \\ 51000 Rijeka, Croatia \\ Phone: +385 (51) 770447 \\ Fax: +385 (51) 686166 \\ www.intechopen.com
}

\author{
InTech China \\ Unit 405, Office Block, Hotel Equatorial Shanghai \\ No.65, Yan An Road (West), Shanghai, 200040, China \\ 中国上海市延安西路65号上海国际贵都大饭店办公楼405单元 \\ Phone: +86-21-62489820 \\ Fax: +86-21-62489821
}


(C) 2012 The Author(s). Licensee IntechOpen. This is an open access article distributed under the terms of the Creative Commons Attribution 3.0 License, which permits unrestricted use, distribution, and reproduction in any medium, provided the original work is properly cited. 